\title{
Repercussions of the COVID-19 Health Crisis In the Peruvian Informal Sector
}

\author{
Vilma Andia-Choquepuma ${ }^{1}$, Daniza Juana Leon-Escobedo ${ }^{2}$, Himer Avila-George ${ }^{3}$, \\ Jorge Sánchez-Garcés ${ }^{4}$, Ruth Elizabeth Villafuerte-Alcántara ${ }^{5}$ and \\ Nelly Rosario Moreno-Leyva ${ }^{6}$
}

\author{
1,2,5,6Facultad Ciencias Empresariales, Universidad Peruana Unión, Juliaca, Perú \\ ${ }^{3}$ Departamento de Ciencias Computacionales e Ingenierías, Universidad de Guadalajara, \\ Ameca Jalisco, Mexico
}

${ }^{4}$ Facultad de Ingeniería y Arquitectura, Universidad Peruana Unión, Juliaca, Perú

Correspondence should be addressed to: Himer Avila-George; himer.avila@academicos.udg.mx

Received date:22 March 2021; Accepted date:20 August 2021; Published date: 23 December 2021

Academic Editor: Ivonne Maria Gil Osorio

Copyright (C) 2021. Vilma Andia-Choquepuma, Daniza Juana Leon-Escobedo, Himer Avila-George, Jorge Sánchez-Garcés, Ruth Elizabeth Villafuerte-Alcántara and Nelly Rosario Moreno-Leyva. Distributed under Creative Commons Attribution 4.0 International CC-BY 4.0

\begin{abstract}
After the World Health Organization declared the outbreak of Coronavirus (COVID-19) a pandemic, the Peruvian government took preventive measures to counteract the spread of the virus by issuing Supreme Decree No. 008-2020-SA. This decree contains prevention and control measures aimed at ports, airports, land entry points, educational centers, transportation and workplaces. The preventive and control measures are aimed at formal economic sectors whose operations are governed by current regulations and laws. The objective of the research was to identify some social restrictions and the effect of the drop in demand and supply caused by the health crisis. The methodology applied for the study was qualitative bibliographic analysis, concluding that the informal sector has been showing repercussions such as a decrease in income, cessation of activities, increase in poverty, increase in unemployment, and expansion of the sector.
\end{abstract}

Keywords: Informality, COVID-19 repercussions, Peruvian Government, health crisis.

Cite this Article as: Vilma Andia-Choquepuma, Daniza Juana Leon-Escobedo, Himer Avila-George, Jorge Sánchez-Garcés, Ruth Elizabeth Villafuerte-Alcántara and Nelly Rosario Moreno-Leyva (2021), "Repercussions of the COVID-19 Health Crisis in the Peruvian Informal Sector ", Journal of Economics Studies and Research, Vol. 2021 (2021), Article ID 948031, DOI: 10.5171/2021.948031 


\section{Introduction}

Currently, the world is facing a sanitary crisis due to COVID-19. For this reason, as of March 16, 2020, the government of Peru declares a health emergency and mandatory social isolation at the national level, taking preventive measures such as closing borders, suspension of academic, commercial, and financial activities, among others (El Peruano, 2020b). In addition, support measures for the formal sector were dictated through the programs "Reactivate Peru," "Business Support Fund," extension for the presentation of monthly tax returns and payment of taxes (Varona \& Gonzales, 2021).

One of the sectors most affected by this health crisis was the informal economic sector; in Peru, this sector comprises companies that are not registered in the National Superintendence of Customs and Tax Administration (SUNAT) lists and have workers who do not enjoy labor benefits. According to Garcia Bernal \& Aguayo (2020), the informal sector does not have protection systems from the state; in addition, it should be taken into account that, in 2019, the informal sector amounted to $73.6 \%$ (INEI, 2020a). The social isolation measures imposed by the Peruvian state have prevented informal workers from developing their activities to generate income that would keep them out of poverty; therefore, by not having savings to be able to face the health crisis, this situation makes them more vulnerable. As shown in Figure 1, the percentage distribution of informal workers is represented by $83.2 \%$ belonging to Micro and Small Enterprises (i.e., 10 million 600 thousand Peruvians).

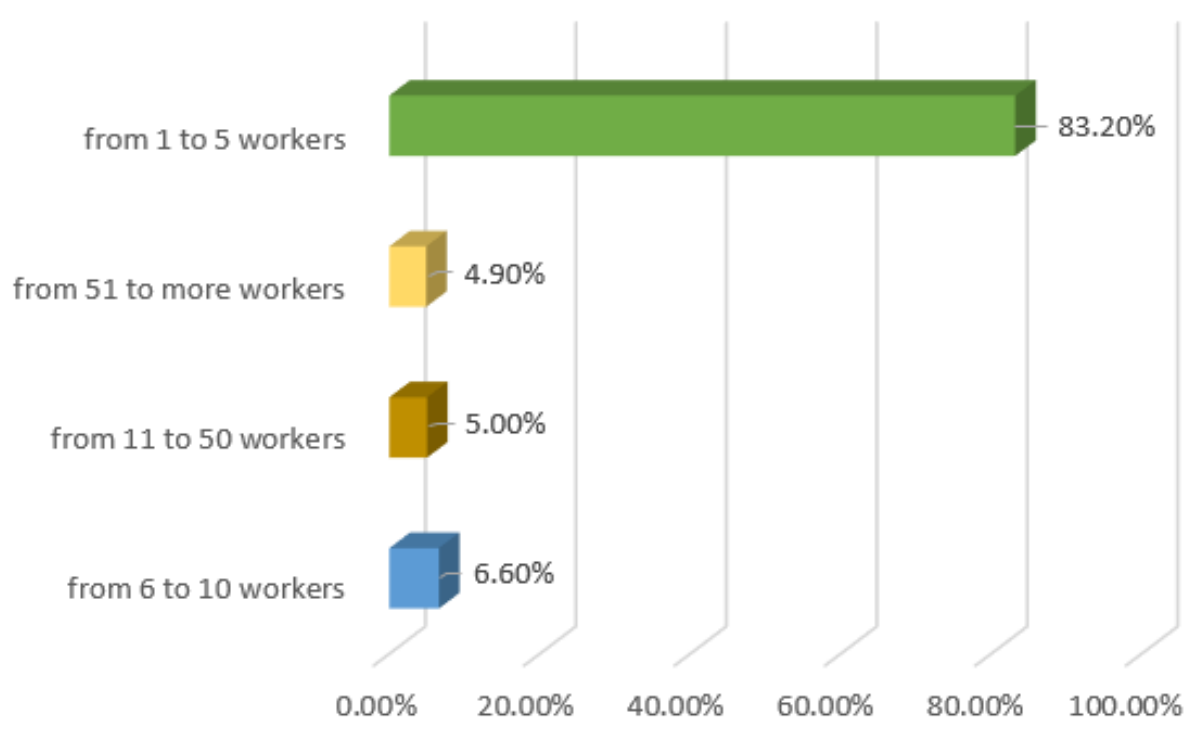

Figure 1: Percentage distribution of informal workers by size of Peruvian companies in 2019

Vilma Andia-Choquepuma, Daniza Juana Leon-Escobedo, Himer Avila-George, Jorge SánchezGarcés, Ruth Elizabeth Villafuerte-Alcántara and Nelly Rosario Moreno-Leyva, Journal of Economics Studies and Research, DOI: 10.5171/2021.948031 
Chacaltana (2020) analyzed the overall impact of the pandemic in the short and medium term, as well as the isolation measures in the labor market. Chacaltana mentions that since workers in the informal sector do not have any protection to reduce the variation of their income when initiating a comprehensive quarantine, the main challenge for the government must have been to quickly organize the transfer of large amounts of resources to the poor and informal sector.

The Organization for Economic Cooperation and Development (OECD) analyzed the effects of social protection during and after COVID-19 in the informal sector; the most affected population segment is young people, followed by adults (Lee et al., 2018). Adults are more vulnerable in this context of the health crisis due to the high mortality rate due to COVID-19; their economic and labor situation is unstable. For their part, Garcia Bernal \& Aguayo (2020) analyzed the macroeconomic impacts of the global economy brought about by the current COVID-19 crisis. They mention that in low and middle-income countries, the impact of this crisis is much more serious, where informal workers, due to confinement measures or working in affected sectors, would impact almost 1.6 billion workers in the informal economy.

This paper presents a proposal for the overall theoretical construction of the incidence of COVID-19 in the informal economic sector in Peru. The proposal has a qualitative hermeneutic format carried out through a literature review.

\section{Development and review stages}

The health crisis affected some economic activities more than others; according to Gamero \& Perez (2020), the most affected are the sectors related to accommodation services, transportation, construction, catering, among others. On the other hand, the least affected companies are those related to the telecommunications, fishing, government, finance, and insurance sectors. According to the Economic Commission for Latin America and the Caribbean (Comisión Económica para América Latina y el Caribe, 2020), support should be provided to vulnerable populations through direct cash transfers. This support should be extended to low-income workers and those in the informal sector developed. Developed and developing countries have different means to cope with this unprecedented crisis which generates international inequalities.

This crisis highlighted the weaknesses of economic systems, making vulnerable economies vulnerable, isolation had a tremendous impact on countries with informal sectors (ILO, 2020). Busso et al. (2020) analyze informality in terms of benefits; the first is that workers who do not obtain health or pension benefits through their jobs are considered informal; the second indicator is the proportion of workers who do not have higher education.

Avedaño-Castro et al. (2020) determine that the social impact of COVID-19, within a context of informality is generated by social, economic, and educational inequalities; epidemics and economic crises have a disproportionate impact because the informal sector has only insufficient economic income to support themselves and their families, which leads to greater social inequality. Peru is no exception to this reality with a high rate of informality; seven out of ten workers are informal workers who do not have basic protections such as social security coverage and do not have a regular income (Gamero \& Perez, 2020).

Taking into account the affected sectors, the Peruvian state, in order to boost its economy, granted financial loans through the "Reactiva Perú" program; 90\% of the beneficiaries of the loans granted by the state are micro and small enterprises, which were delivered at an interest rate of $3 \%$, with a term of twelve months to start payments (El Peruano, 2020a). Díaz Cassou et al. (2020) mentions that the measures

Vilma Andia-Choquepuma, Daniza Juana Leon-Escobedo, Himer Avila-George, Jorge SánchezGarcés, Ruth Elizabeth Villafuerte-Alcántara and Nelly Rosario Moreno-Leyva, Journal of Economics Studies and Research, DOI: 10.5171/2021.948031 
implemented by the government-oriented to companies through "Reactiva Perú" are focused on making loans cheaper for companies and maintaining the payment chain; therefore, the effectiveness of this financial aid that was granted to the formal sector might not be so favorable due to the fact that public spending will be increased to the extent that there are non-payments of the loans granted.

Given this situation, the Peruvian government took certain measures to help this sector, promoting programs so that micro and small companies could formalize, with a $50 \%$ reduction in formalization costs, and by formalizing they could access FONDEMI credits, and they could also have access to participation in bids under the MYPErú purchasing program (El Peruano, 2020c).

It should not be forgotten that, with this pandemic, Peru was one of the countries that had the greatest impact on the economy, since it is estimated that the GDP will fall by around $12 \%$ in 2020 , making it one of the highest contraction figures in the world; this is due, according to Gamero \& Perez (2020), to the high rate of informality that exists in Peru.

\section{Descriptive phase}

Herrera \& Reyes (2020) analyzed the consequences of the measures taken by the Peruvian government in the context of the COVID-19 health crisis. The social immobilization (quarantine) suggested that the modest households were the most vulnerable because they lost their jobs in greater numbers, resulting in a significant decrease in their income.

On the other hand, according to Barrutia et al. (2021), the measures of immobility and social isolation implemented by the Peruvian government to mitigate the advance of COVID-19 between March and June led to the paralyzation of companies and therefore to the dismissal of personnel, a situation that increased unemployment and informality which, in Peru, already had a deep-rooted problem. Jaramillo \& Ñopo (2020) mention that economic activities suffered a hard blow due to the total closure of their productive activities, being that most of them have temporary labor contracts and for short periods such as three months; in this sense, the unemployment rate increased between 16 and $20 \%$. Therefore, for the reactivation of this sector and to help the most vulnerable, the state launched solidarity bonds such as "I stay at home," "rural bond," "independent bond," and "universal family bond." However, according to Frisancho et al. (2020), these economic reactivation measures will only be effective if the government has complete control of the pandemic, so it argues that it should continue with the delivery of solidarity bonds.

Since the informal sector depends on their daily income to survive, according to Mauricio et al. (2020), they are at risk of falling into extreme poverty due to the mandatory confinements imposed by governments. In addition, Ogando \& Abizaid (2020) mention that low-income levels, lack of savings and lack of social protection, lead people working in the informal economy to fall quickly into extreme poverty; at the same time, these workers risk leaving their homes and contracting COVID-19 disease in order to survive. For its part, FAO (2020) estimates that the number of unemployed people as a result of the current crisis will increase by 5.3 million in the best-case scenario; and in the worst-case scenario, it will increase by 24.7 million, these percentages were taken based on the 188 million registered in 2019.

Herrera \& Reyes (2020) state that in any crisis, the most vulnerable people are poor households, who, when they lose their jobs or their only source of income, turn to their savings, which will quickly run out, and will find themselves in a situation of extreme poverty or non-food poverty (INEI, 2020b). For this reason, Florian et al. (2021) conducted interviews by telephone and

Vilma Andia-Choquepuma, Daniza Juana Leon-Escobedo, Himer Avila-George, Jorge SánchezGarcés, Ruth Elizabeth Villafuerte-Alcántara and Nelly Rosario Moreno-Leyva, Journal of Economics Studies and Research, DOI: 10.5171/2021.948031 
home visits to obtain statistical data on employment and unemployment in the capital of Peru, obtaining as results that in the quarter from November 2020 to January 2021 , the unemployment rate in the capital was $13 \%$.

The International Labor Organization mentions that, after the financial collapse and the permanent closure of companies and microenterprises, it is expected that in the coming months, there will be an increase in the informal sector (Lee et al., 2020). Vergara (2020) refers that informal employment will grow since there is no unemployment insurance for workers; he also assures that by the end of 2020, informal work will increase, especially among less qualified self-employed workers, who will resume their activities in the informal sector as a means of subsistence due to the loss of their income. Furthermore, according to Tomaselli (2021), unemployment for a certain number of workers will allow self-employment, which will offer them better salaries than they will be able to obtain as salaried or formal employees.

\section{Interpretive phase}

Considering what has been described regarding the economic impact of the health crisis on the informal sector in the previous phase, the following question is asked: How can informal workers be protected in the face of this health crisis?

Peru, being a country with a high percentage of informality, took measures to deal with COVID-19, implementing the "I stay at home bonus," "rural bonus," "independent bonus," and the "universal bonus," however, these support measures were not able to reach the entire informal sector because there is a considerable increase in the unemployed and migrant population. This sector was also visibly affected by the confinement and social distancing, suffering repercussions such as the loss of their income, the closing of their businesses, and the change of the line of business that they had to do to survive during the crisis. This non-poor but vulnerable population was living on the edge, they saw as an option to get out of poverty by entering informal trade; on the other hand, it should be taken into account that this population lives from day to day, which is why during this health crisis many of them returned to the ranks of poverty, spent all their savings and were left without any capital to restart their previous activities.

Gómez (2007)mentions that: countries with the more informal economy are characterized by a high level of poverty, slow economic growth, where benefits are concentrated in a few; informality also limits the ability to adapt to situations such as COVID-19; the low coverage of social security systems in these countries makes it impossible to protect citizens from the negative effects of the pandemic; it must also be taken into account that cash transfer programs for those most affected, do not replace the loss of income from the informal sector. Faced with this reality, the Peruvian government did not take measures to solve this social problem of informality; according to Gamero \& Perez (2020), 7 out of 10 workers are informal, so the measures taken in this health crisis should have been prioritized to this sector.

\section{Theoretical construct}

During the COVID-19 health crisis, Peru was one of the countries that took drastic preventive measures against the spread of COVID-19 in order to support the informal sector; the Peruvian state promotes monetary subsidies aimed at people who are not on the payroll, people in poverty, according to INEI data, but these subsidies failed to activate the economy of this sector, these bonds granted by the state only serve as temporary help, not having total control of the pandemic. On the other hand, there were regulations taken by the state for the

Vilma Andia-Choquepuma, Daniza Juana Leon-Escobedo, Himer Avila-George, Jorge SánchezGarcés, Ruth Elizabeth Villafuerte-Alcántara and Nelly Rosario Moreno-Leyva, Journal of Economics Studies and Research, DOI: 10.5171/2021.948031 
economic reactivation. However, these regulations approved by the state are within its scope to favor formal companies. In this sense, the present work makes a global theoretical proposal that, according to Botero (2000), consists of a review of state of the art, of points of view of different authors; where trends and limitations are observed in order to then develop proposals based on an interpretation. Therefore, in this review of the impact of the health crisis on the informal sector, it was possible to identify factors that impacted this sector, which represents a good number of the population in Peru, as shown in Table 1.
Thus, the informal sector was affected during the current health crisis (atypical phenomenon), having to assume certain negative effects such as a decrease in income, cessation of activities, possible return to poverty, unemployment, and expansion of the informal economy; on the other hand, the unemployment experienced during the pandemic brought with it an increase in the informal sector. With this, the research emphasizes these factors in order to understand the repercussions for better decision-making by the Peruvian government.

Tabla 1: Summary of the impact the informal sector had and has during the pandemic

\begin{tabular}{|c|c|c|}
\hline Subcategory & Observation & Interview \\
\hline $\begin{array}{l}\text { Decrease in } \\
\text { income }\end{array}$ & $\begin{array}{l}\text { The measures adopted by the } \\
\text { Peruvian government affected } \\
\text { independent workers in the } \\
\text { informal sector, who were forced } \\
\text { to temporarily close their } \\
\text { businesses. }\end{array}$ & $\begin{array}{l}\text { In the interview conducted with E001, who sells } \\
\text { shoes in Jr. Moquegua, located in the district of } \\
\text { San Roman, department of Puno, he mentioned } \\
\text { that during the pandemic, during the reactivation } \\
\text { period, his income decreased significantly, and } \\
\text { consumers decided to buy more basic necessities } \\
\text { and cleaning products. }\end{array}$ \\
\hline $\begin{array}{l}\text { Cessation of } \\
\text { activities }\end{array}$ & $\begin{array}{l}\text { The pandemic caused many } \\
\text { microenterprises to close their } \\
\text { businesses due to the lack of } \\
\text { security and sanitation measures. }\end{array}$ & $\begin{array}{l}\text { In the interview conducted with E001, who sells } \\
\text { shoes in Jr. Moquegua, located in the district of } \\
\text { San Roman, department of Puno, he mentioned } \\
\text { that during the pandemic he was forced to close } \\
\text { his business, which affected his income, and } \\
\text { during the quarantine he did not make any sales. }\end{array}$ \\
\hline $\begin{array}{l}\text { Potential } \\
\text { return to } \\
\text { poverty }\end{array}$ & $\begin{array}{l}\text { With the quarantine that was } \\
\text { decreed in Peru, there was an } \\
\text { increase in poverty because many } \\
\text { people found a way out of poverty } \\
\text { by engaging in informal trade, and } \\
\text { with this decree many of these } \\
\text { people stopped working, so that } 1.1 \\
\text { million Peruvians belonging to the } \\
\text { middle class will become } \\
\text { vulnerable, and } 949,429 \text { of the } \\
\text { vulnerable class will fall back into } \\
\text { poverty. }\end{array}$ & $\begin{array}{l}\text { In an interview with Mr. E001, who sells shoes in } \\
\text { Jr. Moquegua, located in the district of San Roman, } \\
\text { department of Puno, he mentioned that during } \\
\text { the pandemic he spent the little he had saved, and } \\
\text { now with the decrease in demand for the } \\
\text { products he offers, his economy continues to be } \\
\text { affected. }\end{array}$ \\
\hline & The companies, seeing their & In the interview with E002, who is an early \\
\hline
\end{tabular}

Vilma Andia-Choquepuma, Daniza Juana Leon-Escobedo, Himer Avila-George, Jorge SánchezGarcés, Ruth Elizabeth Villafuerte-Alcántara and Nelly Rosario Moreno-Leyva, Journal of Economics Studies and Research, DOI: 10.5171/2021.948031 


\begin{tabular}{|l|l|l|}
\hline Unemployment & $\begin{array}{l}\text { income considerably affected, } \\
\text { massively laid off many workers. } \\
\text { Although there was an economic } \\
\text { reactivation plan, it did not have } \\
\text { the expected results since } \\
\text { according to the INEI there are 2.6 } \\
\text { million companies in Peru, which } \\
\text { represents a very low number. }\end{array}$ & $\begin{array}{l}\text { the pandemic, the private educational institution } \\
\text { where she worked was affected, many parents } \\
\text { decided to take their children out of school to take } \\
\text { them to a state school, and soon after the } \\
\text { quarantine was declared, she lost her job and } \\
\text { became part of the large number of unemployed. }\end{array}$ \\
\hline $\begin{array}{l}\text { The expansion of } \\
\text { the informal } \\
\text { economy. }\end{array}$ & $\begin{array}{l}\text { Before the COVID-19 crisis, Peru } \\
\text { had 72\% of the informal economy. } \\
\text { And now with the new layoffs in } \\
\text { the formal sector, the informal } \\
\text { economy is increasing. }\end{array}$ & $\begin{array}{l}\text { In the interview with E002, who is an early } \\
\text { childhood educator in the district of San Roman, } \\
\text { department of Puno, she mentioned that due to } \\
\text { the condition in which she found herself } \\
\text { (unemployed) she decided to sell extracts, } \\
\text { cleaning products and masks, which helped her to } \\
\text { support herself economically; she is a single } \\
\text { mother and must support her family. }\end{array}$ \\
\hline
\end{tabular}

\section{Discussions}

From interviews with informal workers, we agree that during the confinement and restrictions during the quarantine, many workers in the informal sector saw their income affected, as their activities ceased, and they had to look for other means of subsistence. Jaramillo \& Ñopo (2020) stated that during the quarantine imposed by the State, there were serious consequences, such as the closure of many microenterprises with more than ten workers; despite this, the State accelerated the reactivation of the economy as of July 2020, and despite all these efforts, there are still more than one million people currently looking for work.

Many micro-entrepreneurs in the informal sector started their activities at a rate of $50 \%$, hoping to improve their income. On the other hand, there is a group that during the quarantine were left without any capital, which had to close their businesses permanently, on the other hand, the newspaper El Peruano states that at the end of September 2020, there were 15,000 microenterprises formalized, which exceeds the number of registered in 2019, and that it is expected that by the end of 2020 at least 30,000 micro-enterprises will be registered, due to the strategies that are being implemented so that more entrepreneurs opt for the formal sector; In addition to the programs that were launched by the State as "reactiva Peru," the business support fund (FAE Mype) among other measures that were taken to finance companies that were without working capital.

Under these perspectives, we have to take into account the group of unemployed who opted for informality, and we also have to take into account that many companies decided to formalize in the dates provided by law, only to access the programs granted by the State without any success; These micro-enterprises that are used to not paying any taxes will be affected with their income and will decide to be part of the informal sector, thus concluding that the increase of informality is inevitable. However, the Minister of Economy and Finance Waldo Mendoza, in an interview with the newspaper El Peruano (2020b), stated that by 2021 the Peruvian economy would recover quickly, the State will make contributions for the economic reactivation.

Vilma Andia-Choquepuma, Daniza Juana Leon-Escobedo, Himer Avila-George, Jorge SánchezGarcés, Ruth Elizabeth Villafuerte-Alcántara and Nelly Rosario Moreno-Leyva, Journal of Economics Studies and Research, DOI: 10.5171/2021.948031 


\section{Conclusions}

As a result of company closures, the number of unemployed increased, forcing many of these workers to earn income through informal economic activities. Approximately, the informal sector during this pandemic has reached $72.4 \%$ of the economic activity. In this sense, the Peruvian state has given a series of aid measures for the economic reactivation; and has focused its aid to this sector, assigning an economic subsidy such as the Universal Family Bonus, being that many of these Micro-enterprises did not receive the benefits granted to formal companies.

Likewise, this pandemic situation has caused many micro-entrepreneurs to see an opportunity to make their companies formal, with the policies decreed to support these entrepreneurs to enjoy the benefits of the formal sector. Therefore, this process must be consolidated in order to achieve a gradual reactivation of economic activity.

From our perspective, it is recommended that the Peruvian government take measures in crises such as COVID-19 thinking in the long term, taking it as an opportunity to reduce informality; in addition, certain measures should be taken considering that Peru is a country with a high rate of informality, Espacios which can have repercussions in a possible return to poverty. The future labor agenda should combine health measures with economic measures to sustain existing jobs and move from informality to formality.

\section{References}

- Avedaño-Castro, W. R., HernandezSuarez, C. A., \& Prada-Nuñez, R. (2020). Impacto social del Covid-19 en un contexto de informalidad., 41(42), 3951. https://doi.org/10.48082/espaciosa20v41n42p04

- Barrutia, I., Sánchez, R., \& Silva, H. (2021). Consecuencias económicas y sociales de la inamovilidad humana bajo COVID-19: caso de estudio Perú. Lecturas de Economía, 94. https://doi.org/10.17533/udea.le.n94a 344397

- Botero, C. H. (2000). Un modelo para investigación documental: guía teóricopráctica sobre construcción de Estados del Arte con importantes reflexiones sobre la investigación. Señal Editora.

- Busso, M., Camacho, J., Messina, J., \& Montenegro, G. (2020). The Challenge of Protecting Informal Households during the COVID-19 Pandemic: Evidence from Latin America. Inter-American Development Bank, Paper No IDB-DP780, 1-25.

- Chacaltana, J. (2020). ¿Respuesta rápida a la COVID-19 en un contexto de alta informalidad? El caso del Perú. Organización Internacional Del Trabajo, 1-8.

- Comisión Económica para América Latina y el Caribe. (2020). América Latina y el Caribe ante la pandemia del COVID-19. Informe Especial Covid-19, 1, 1-15.

- Díaz Cassou, J., Deza, M. C., \& Moreno, K. (2020). Perú: Desafíos del desarrollo en el post COVID-19. In Banco Interamericano de DEsarrollo: Vol. IDBDP-007.

https://doi.org/10.18235/0002658

- El Peruano. (2020a). Decreto Legislativo 1455. In Diario Oficial Bicentenario el Peruano (pp. 2-6). Editora Perú.

- El Peruano. (2020b). Decreto Supremo 044-2020-PCM. In Diario Oficial Bicentenario el Peruano (pp. 10-13).

- El Peruano. (2020c). Decretos de urgencia 029-2020. In Diario Oficial Bicentenario el Peruano (pp. 2-7).

- FAO. (2020). Repercusiones de la enfermedad por coronavirus (COVID19) en los trabajadores informales. FAO - Organización de Las Naciones Unidas

Vilma Andia-Choquepuma, Daniza Juana Leon-Escobedo, Himer Avila-George, Jorge SánchezGarcés, Ruth Elizabeth Villafuerte-Alcántara and Nelly Rosario Moreno-Leyva, Journal of Economics Studies and Research, DOI: 10.5171/2021.948031 
Para La Alimentación y La Agricultura, 8. https://doi.org/10.4060/ca8560es

- Florian, S., Ruiz, R., Valle, N., \& Elías, M. (2021). Situación del mercado laboral en Lima metropolitana. INEI - Instituto Nacional de Estadistica e Informatica.

- Frisancho, V., Lavado, P., Liendo, C., \& Saavedra, J. C. (2020). La formalización del empleo, la protección de las familias y la construcción de una sociedad más igualitaria. Inter-American Development Bank, IDB-DP-805, 1-22.

- Gamero, J., \& Perez, J. (2020). Perú: Impacto de la COVID-19 en el empleo y los ingresos laborales. Organización Internacional Del Trabajo, 1-38.

- Garcia Bernal, N., \& Aguayo, I. (2020). Impactos macroeconómicos del covid 19 en el mercado laboral. Bliblioteca Del Congreso Nacional de Chile, 1-15.

- Gómez, L. (2007). La informalidad en la economía, algo incuestionable. Semestre Económico, 10(19), 47-67.

- Herrera, T., \& Reyes, A. (2020). Empobrecimiento de los hogares y cambios en el abastecimiento de alimentos por la COVID-19 en Lima, Perú. Ar@cne, 24(243), 1-23. https://doi.org/10.1344/ara2020.243.3 1627

- ILO. (2020). COVID-19 crisis and the informal economy: Immediate responses and policy challenges. International Labour Organization.

- INEI. (2020a). Perú: Condiciones de vida de la población en riesgo ante la pandemia del COVID-19. Encuesta Nacional de Hogares - ENAHO 2019, 1155.

- INEI. (2020b). Población Peruana 2020. Estado de La Población Peruana 2020, 1-50.

- Jaramillo, M., \& Ñopo, H. (2020). covid19 y shock externo impactos económicos y opciones de política en el Perú. Journal of Chemical Information and Modeling, 53(9), 1689-1699.

- Lee, S., Marcadent, P., \& Diez de Medina, R. (Eds.). (2018). Women and Men in the Informal Economy: A Statistical Picture (Third Edit). International Labour Office.

- Lee, S., Vanhuynegmen, P., \& Chacaltana, J. (2020). ¿Respuesta rápida a la covid19 en un contexto de alta informalidad? El caso del Perú. Organización Mundial Del Trabajo, 1-8.

- Mauricio, R., Torres, S., \& Chaparro Hernández, S. (2020). Un piso de protección social para preservar la vida: informalidad, pobreza y vulnerabilidad en tiempos de COVID-19. Centro de Investigaciones Para El Desarrollo, FCECID No 35.

- Ogando, A. C., \& Abizaid, O. (2020). ¿Cómo se enfrentan a la COVID-19 las vendedoras y vendedores ambulantes de Perú? In Trabajadoras y trabajadores en empleo informal durante la crisis de la COVID-19 (pp. 32-35). Women in Informal Employment: Globalizing and Organizing.

- Tomaselli, A. (2021). Determinantes departamentales y estimación del riesgo distrital del trabajo informal en el Perú. In Determinantes departamentales y estimación del riesgo distrital del trabajo informal en el Perú. Documentos de Proyectos (LC/TS.2021/12). Comisión Económica para América Latina y el Caribe.

- Varona, L., \& Gonzales, J. R. (2021). Dynamics of the impact of COVID-19 on the economic activity of Peru. PLoS ONE, $16(1$ January), 1-30. https://doi.org/10.1371/journal.pone.0 244920

- Vergara, A. (2020). La crisis del COVID19 como Aleph peruano. In R. Rojas \& V. Pettina (Eds.), América Latina: Del estallido social a la implosión económica y sanitaria post COVID-19. Crítica.

Vilma Andia-Choquepuma, Daniza Juana Leon-Escobedo, Himer Avila-George, Jorge SánchezGarcés, Ruth Elizabeth Villafuerte-Alcántara and Nelly Rosario Moreno-Leyva, Journal of Economics Studies and Research, DOI: 10.5171/2021.948031 